\title{
Octreotide effectively decreases mucosal damage in experimental colitis
}

\author{
R Eliakim, F Karmeli, E Okon, D Rachmilewitz
}

\begin{abstract}
The effect of octreotide, a synthetic analogue of somatostatin, on the modulation of the acetic acid model of experimental colitis was examined. Colitis was induced by intracolonic administration of $2 \mathrm{ml}$ of $5 \%$ acetic acid. The inflammatory response elicited by the acetic acid resulted in increased colonic synthesis of platelet activating factor, leukotriene $\mathbf{B}_{\mathbf{4}}$ and decreased mucosal somatostatin levels. Subcutaneous administration of octreotide (10 $\mu \mathrm{g} / \mathrm{rat}) 1$ hour before or immediately after damage induction, as well as 1 and 23 hours after acetic acid application, resulted in a significant reduction in mucosal damage. The protective effect was accompanied by a significant reduction in platelet activating factor activity, leukotriene $B_{4}$, and vasoactive intestinal peptide concentrations. There were no significant changes in mucosal leukotriene $\mathrm{C}_{4}$ and calcitonin gene related peptide levels. This study shows that aceticl acid induced colitis is pharmacologically manipulated by octreotide. The mechanism of action of octreotide has not yet been fully determined. The potential use of octreotide in treating active inflammatory bowel disease remains to be evaluated.
\end{abstract}

(Gut 1993; 34: 264-269)

Somatostatin, a cyclic tetradecapeptide, is widely distributed throughout the gastrointestinal tract. The highest concentrations of somatostatin secreting cells are found in the antrum, duodenum, and pancreas. ${ }^{1-3}$ Minute amounts are found in neural cells along with other neuropeptides, as well as within the mucosal and submucosal layers in the human small intestine and colon. ${ }^{1+}$ Among the biological actions of somatostatin in the gut is its ability to inhibit neuroendocrine secretion of gastrin, vasoactive intestinal peptide (VIP), and motilin - all known for their ability to induce diarrhoea. ${ }^{\prime 2}$ Somatostatin decreases intestinal fluid secretion and stimulates sodium and chloride absorption. ${ }^{56}$ In animal models, somatostatin inhibits proliferation of gut epithelial and ileal crypt cells. ${ }^{78}$

Somatostatin concentrations in the mucosa and submucosa of patients with inflammatory bowel disease were reported to be either reduced or unaltered..$^{8-11}$ High concentrations of circulating immunoreactive somatostatin were found in patients with active ulcerative colitis but these returned to normal on remission. ${ }^{12}$ We found low colonic mucosal somatostatin values in patients with active ulcerative colitis and normal concentrations on remission. ${ }^{13}$ When used for treatment, somatostatin should be administered continuously because of its very short half life. Octreotide, its synthetic analogue, has a longer half life, is administered subcutaneously, and its serum concentration increases in linear fashion with increased doses. ${ }^{2}$ Octreotide is currently the most effective drug for various diarrhoeal disorders-carcinoid syndrome, and vipoma, and is beneficial in ileostomy diarrhoea, short bowel syndrome, AIDS, and diabetic diarrhoea. ${ }^{21+19}$

In the present study the possible modulation of acetic acid induced experimental colitis ${ }^{20}$ by octreotide was evaluated.

\section{Methods}

ACETIC ACID INDUCED COLITIS

Hebrew University strain male rats, 200-250 g body weight, were fasted for 24 hours. Under light ether anaesthesia, a midline abdominal incision was made, the colon was isolated, and the junction of caecum and ascending colon was ligated. Two $\mathrm{ml}$ of $5 \%$ acetic acid were injected into the lumen of the colon at its proximal part through a $25 \mathrm{G}$ needle, followed by $3 \mathrm{ml}$ of air, which cleared most of the acetic acid from the colon..$^{20}$ The midline incision was closed. Twenty four hours later the rats were killed. The colon was isolated and a $10 \mathrm{~cm}$ segment of the distal colon proximal to the anus was resected, its lumen was rinsed with ice cold saline, and it was weighed. A cross section was obtained for histology and the whole mucosa was scraped, minced, and divided into samples for radioimmunoassay (RIA) and platelet activating factor (PAF) determination. Treated rats received octreotide $(10 \mu \mathrm{g} / \mathrm{rat})$ subcutaneously, 1 hour before and 1 and 23 hours after damage induction. Another group of rats received octreotide $(10 \mu \mathrm{g} / \mathrm{rat})$ immediately after and 8 and 23 hours after damage induction by acetic acid.

\section{DETERMINATION OF MUCOSAL DAMAGE}

Mucosal damage was quantitated by the scoring system of Wallace et al. ${ }^{21}$ In this system: $0=$ no damage; $1=$ hyperaemia, no ulcers; $2=$ linear ulceration without hyperaemia or bowel wall thickening; $3=$ linear ulcer with inflammation at one site; $4=$ two or more sites of ulceration and inflammation; $5=$ two or more sites of major ulceration and inflammation, or one major site of damage extending more than $1 \mathrm{~cm}$ along the length of the colon; $6-10=$ when area of ulceration and inflammation extends more than $2 \mathrm{~cm}$ along the length of the colon, the score is increased by one mark for each additional $\mathrm{cm}$ of involvement. Mucosal damage was also measured macroscopically and expressed in $\mathrm{mm}^{2} /$ rat. All scoring and measurements of damage were performed by 
two observers. Interobserver variability was less than $1 \%$ error. For the purpose of scoring, inflammation was defined as hyperaemia and thickening of the bowel wall. The time taken to assess the extent of mucosal damage was less than a few minutes.

\section{MORPHOLOGICAL STUDIES}

Sections of colon were obtained from the same areas of the large intestine, fixed in phosphate buffered formaldehyde, embedded in paraffin and routine $5 \mu \mathrm{m}$ sections were prepared. Tissues were routinely stained with haematoxylin and eosin and evaluated blindly by light microscopy.

\section{DETERMINATION OF LIPOXYGENASE PRODUCTS} One hundred and fifty mg of mucosa were placed in preweighed tubes containing $1 \mathrm{ml}$ of phosphate buffer $(50 \mathrm{mM}, \mathrm{pH} \mathrm{7 \cdot 4})$. The mucosa was minced with scissors and centrifuged in an Eppendorf centrifuge for 10 seconds. The pellet was resuspended in $1 \mathrm{ml}$ of the above buffer, incubated for 1 minute in a vortex mixer, indomethacin $(10 \mu \mathrm{g})$ was added, and the tubes were centrifuged for 60 seconds. The supernatants were kept at $-20^{\circ} \mathrm{C}$ until RIAs were performed. The capability of the mucosa to generate leukotriene $\mathrm{C}_{4}\left(\mathrm{LTC}_{4}\right)$ and $\mathrm{B} 4\left(\mathrm{LTB}_{4}\right)$ was expressed as $\mathrm{ng} / \mathrm{g}$ wet tissue weight.

MEASUREMENT OF LTB

$\mathrm{LTB}_{4}$ immunoreactivity was determined by a RIA kit (Amersham, TRK 940). The assay combines the use of a high specific activity $\mathrm{LTB}_{4}$ tracer, an antiserum specific for $\mathrm{LTB}_{4}$ (cross reactivity $100 \%$ ), and a leukotriene standard (range 1.6 to $200 \mathrm{pg} /$ tube). The specific binding of tracer is $42.5 \%$, and non-specific binding is $2 \cdot 4 \%$. Fifty per cent $\mathrm{B} / \mathrm{Bo}$ displacement is obtained with $15 \mathrm{pg} /$ tube and $90 \% \mathrm{~B} / \mathrm{Bo}$ displacement with $2 \cdot 2 \mathrm{pg} /$ tube of $\mathrm{LTB}_{4}$. The percentage coefficient of variation $(\mathrm{CV})$ for within assay precision ranges from 8.26 (low) to 8.61 (high) $(n=20)$. The percentage $\mathrm{CV}$ for the precision profile of the assay (10 assays of standard curve) ranges from $2 \cdot 31$ to $6 \cdot 3$. The percentage $\mathrm{CV}$ for between assay reproducibility ranges from 0.81 to $5 \cdot 78(n=10)$.

MEASUREMENT OF LTC

$\mathrm{LTC}_{4}$ immunoreactivity was determined by RIA (Amersham, TRK 905). The assay combines the use of a high specific activity $\mathrm{LTC}_{4}$ tritiated tracer with a monoclonal antibody specific for $\mathrm{LTC}_{4}$ and $\mathrm{LTC}_{4}$ standard (8-500 pg/tube). The assay uses highly specific $\mathrm{LTC}_{4}$ antiserum (cross reactivity $=100 \%$ ) and has low cross reactivity with leukotriene $\mathrm{D}_{4}\left(\mathrm{LTD}_{4}\right)(<5 \%)$. The specific binding of tracer is $40 \%-45 \%$ and non-specific binding is $1 \%-3 \%$. Fifty per cent $\mathrm{B} / \mathrm{Bo}$ displacement is obtained with $34 \mathrm{pg} /$ tube, and $80 \% \mathrm{~B} / \mathrm{Bo}$ displacement with $9.5 \mathrm{pg} /$ tube of $\mathrm{LTC}_{4}$. The percentage $\mathrm{CV}$ for within assay precision ranges from 7.68 (low) to 3.94 (high). The percentage $\mathrm{CV}$ for the precision profile of the assay ranges from 1.64 to $3.49(n=9)$. The percentage $C V$ for between assay reproducibility ranges from 1.64 to $3 \cdot 49(\mathrm{n}=9)$.

\section{PAF DETERMINATION}

Extraction of PAF from colonic mucosa

To extract PAF from the mucosa, $0.5 \mathrm{ml}$ of ethanol $80 \%$ was added to preweighed colonic mucosa (20-30 mg) 24 hours before performance of the aggregation assay.

\section{Platelet preparation}

Fifty $\mathrm{ml}$ of rabbit venous blood were collected into Falcon tubes, mixed with $1 \mathrm{ml} 0.2 \mathrm{M}$ ethylenediamine-tetra-acetic acid and centrifuged for 20 minutes at $1600 \mathrm{rpm}$. Plasma was transferred to another tube and centrifuged for 15 minutes at $3000 \mathrm{rpm}$. The platelet pellet was reconstituted with a washing buffer (pH 6.5) containing 2.6 mM KCl. $1 \mathrm{mM} \mathrm{MgCl}_{2}, 137 \mathrm{mM}$ $\mathrm{NaCl}, \quad 0.2 \mathrm{mM}$ ethyleneglycol-bis (betaaminoethylether)-N,N'-tetraacetic acid, $5.5 \mathrm{mM}$ glucose, and $0 \cdot 25 \%$ gelatine and centrifuged for 15 minutes at $3000 \mathrm{rpm}$. The platelet pellet was resuspended in the above buffer and treated with $0.1 \mathrm{mM}$ aspirin for 15 minutes at room temperature, followed by another centrifugation for 15 minutes at $3000 \mathrm{rpm}$. Platelets were resuspended in washing buffer at appropriate concentrations for the measurement of platelet aggregation.

\section{AGGREGATION ASSAY}

PAF activity was measured by platelet aggregation using a Chrono-Log Corporation aggregometer. Platelets were stirred in $400 \mu \mathrm{l}$ buffer containing $2.6 \mathrm{mM} \mathrm{KCl}, 1 \mathrm{mM} \mathrm{MgCl}_{2}$ $137 \mathrm{mM} \mathrm{NaCl}, 12 \mathrm{mM} \mathrm{NaHCO}, 1.5 \mathrm{mM}$ $\mathrm{CaCl}_{2}, 5.5 \mathrm{mM}$ glucose, $0 \cdot 25 \%$ gelatine, $1 \mathrm{mM}$ creatine phosphate and $10 \mathrm{U} / \mathrm{ml}$ creatine phosphokinase $(\mathrm{pH} \mathrm{7 \cdot 4)}$. Samples of $10 \mathrm{ul}$ were added and aggregation recorded. WEB 2086 BS inhibited dose dependently $(0 \cdot 17-17 \mu \mathrm{M})$ the PAF induced platelet aggregation $(r=0.891$; $y=140-8 \cdot 8 x)$.

\section{Extraction of neuropeptides}

Twenty to $30 \mathrm{mg}$ of colonic mucosa were frozen in liquid nitrogen, weighed, and homogenised in 10 volumes of acetic acid $2 \mathrm{M}$, containing $10 \mathrm{mM}$ mercaptoethanol and phenylmethylsulphonylfluoride $(1 \mu \mathrm{g} / \mathrm{ml})$. The homogenate was centrifuged for 10 minutes at $3000 \mathrm{rpm}\left(4^{\circ} \mathrm{C}\right)$. The supernatant was transferred to another tube, the pellet rehomogenised and centrifuged as above. Supernatants were combined and kept at $-20^{\circ} \mathrm{C}$ until they were lyophilised. After lyophilisation the protein was resuspended in $1 \mathrm{ml}$ phosphate buffer, $50 \mathrm{mM}, \mathrm{pH} 7 \cdot 4$, containing $\mathrm{NaCl}$ $145 \mathrm{mM}$, gelatin $0 \cdot 1 \%$ and $\mathrm{NaN}_{3} 0 \cdot 02 \%$. Somatostatin, VIP, and calcitonin gene related peptide (cGRP) were determined by RIA.

\section{Somatostatin RIA}

Somatostatin RIA employs simultaneous addition of sample or standard (range $0-500$ 


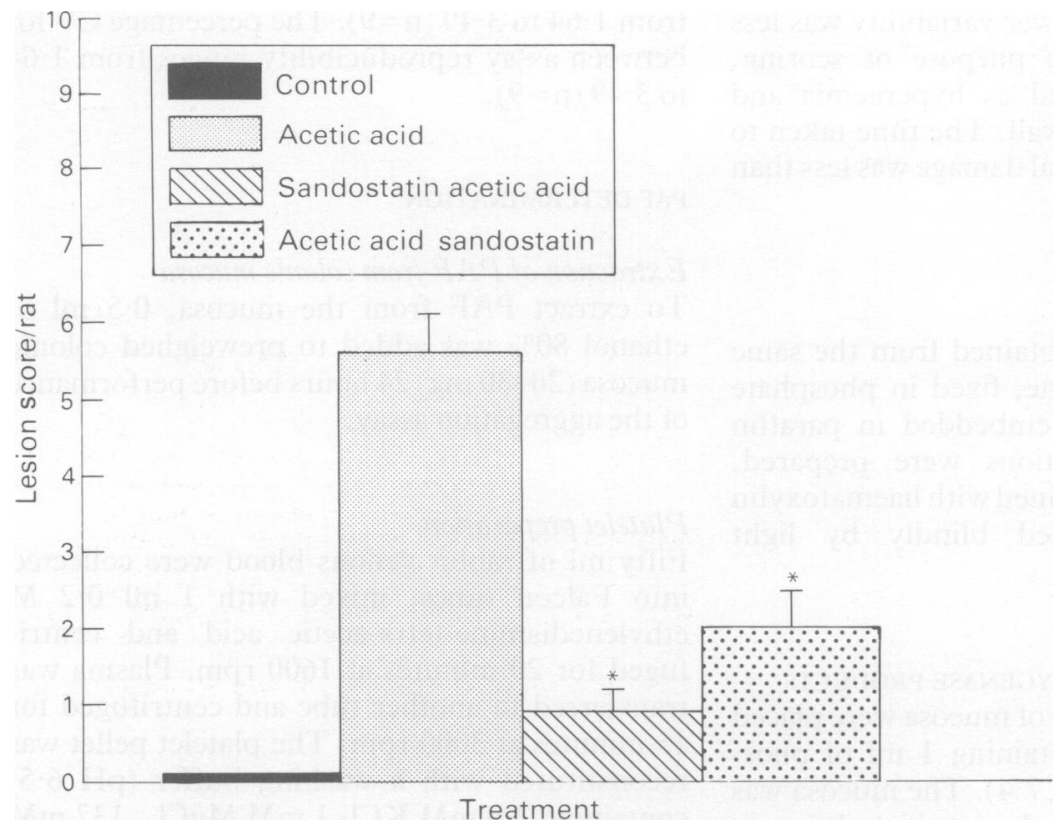

Figure 1: Colonic lesion score 24 hours after intracolonic administration of 5\% acetic acid with or without octreotide cotreatment. Results are mean (SEM) of 8 to 11 rats per group. $\star$ Significantly different from acetic acid treated rats; $p<0 \cdot 05$, Mann-Whitney non-parametric test and Student's test.
cGRP RIA

The cGRP RIA employs simultaneous addition of samples or standard (range 0-1000 fmol), rabbit antiserum to cGRP human (binding capacity $35 \%-40 \%$ and (2-[ ${ }^{125}$ I] iodohistidyl $\left.{ }^{10}\right)$ cGRP followed by five days incubation at $4^{\circ} \mathrm{C}$. Phase separation is accomplished by the addition of dextran/charcoal suspension. The tubes are centrifuged for 20 minutes at $2000 \mathrm{~g}$, bound (supernatant) and free (pellet) are counted in a Packard auto-gamma scintillation spectrometer.

\section{STATISTICAL ANALYSIS}

Data are expressed as median, range, and mean (SEM). Statistical analysis for significant differences was performed according to the Student's $t$ test for unpaired data and the MannWhitney non-parametric test.

\section{MATERIALS}

Acetic acid (Frutarom, Israel); aspirin (Aspegic, Lab Egic, Amilly, France); creatine phosphate, creatine phosphokinase, fatty acid free bovine serum albumin, $\mathrm{LTC}_{4}$, indomethacin (all from Sigma Laboratories, Israel); PAF (C18) (Bachem, Switzerland); octretotide - sandostatin (Sandoz Ltd, Basle, Switzerland); $\mathrm{LTB}_{4}$ RIA; $\mathrm{LTC}_{4}$ RIA (Amersham, England); somatostatin and cGRP RIA (Amersham, England). VIP RIA (Incstar Corp, Stillwater, Minnesota, USA). statin followed by an overnight incubation at $4^{\circ} \mathrm{C}$. Phase separation was accomplished by the addition of a complex goat anti-rabbit serum, carrier rabbit serum, and polyethylene glycol. After 25 minutes incubation the tubes were centrifuged, decanted, and counted in a Packard auto-gamma scintillation spectrometer. The percentage cross reactivity of somatostatin antibody was less than 0.007 for each of the following peptides: beta endorphin, substance $P$, leucine enkephalin, methionine enkephalin, arginine vasopressin, insulin, thyroid releasing hormone, and VIP.

\section{VIP RIA}

VIP was measured by RIA using delayed tracer addition to increase sensitivity. Sample or standard (range 0-290 pg/ml) and rabbit antiVIP (binding capacity $40 \%-50 \%$ ) were added followed by a 24 hour incubation at $4^{\circ} \mathrm{C}$. ${ }^{125} \mathrm{I}-$ VIP was then added followed by a second incubation for 24 hours at $4^{\circ} \mathrm{C}$. Preprecipitated carrier, second antibody, and polyethylene glycol were added in a single step. The assay was incubated for a further two hours, centrifuged, decanted, and counted in a gamma counter for at least 60 seconds. The percentage cross reactivity of the VIP and antibody was less than $0 \cdot 1$ for each of the following peptides: somatostatin, p-motilin, GIP, glucagon, GRP, gastrin 17, gastrin 34, psecretin, PPP, p-proinsulin, p-insulin, cholecystokinin (CCK-8), substance $P$, neurotensin, methionine enkephalin, leucine enkephalin, and bombesin. The percentage $\mathrm{CV}$ for within assay variation ranges from $\pm 1 \cdot 9$ (low) to $\pm 3 \cdot 0$ (high) $(n=5)$. The percentage $\mathrm{CV}$ for between assay variation ranges from 9.58 (low) to $7 \cdot 07$ (high) $(n=73)$. 


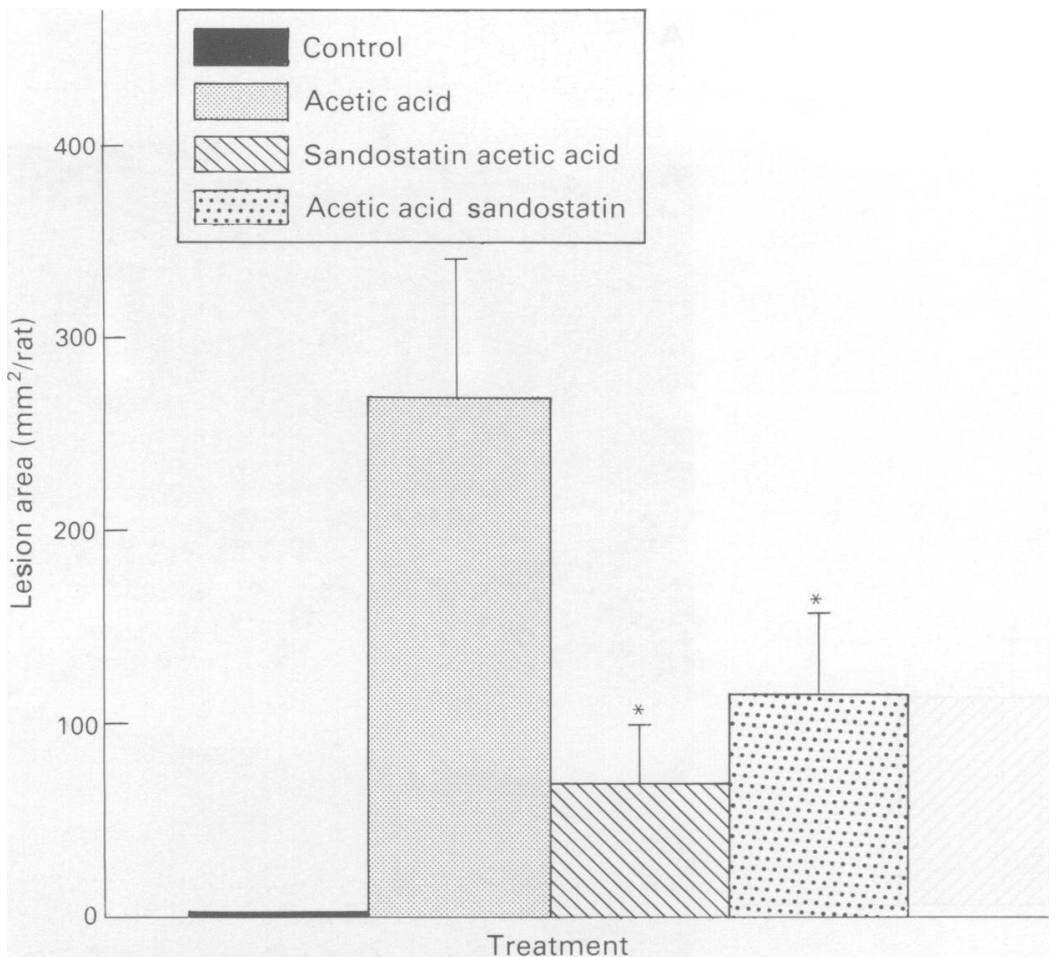

Figure 2: Colonic lesion area 24 hours after intracolonic administration of 5\% acetic acid with or without octreotide cotreatment. Results are mean (SEM) of 8 to 11 rats per group. $\star$ Significantly different from acetic acid treated rats, $p<0 \cdot 05$, Mann-Whitney non-parametric test and Student's t test.
EFFECTS OF OCTREOTIDE ON MUCOSAL DAMAGE Treatment with octreotide, $10 \mu \mathrm{g} /$ rat twice daily immediately after induction of damage by $5 \%$ acetic acid, significantly reduced mucosal damage. It reduced the lesion area by $57 \%$ (from $268(71) \mathrm{mm}^{2}$ in the acetic acid treated rats to 114 (42) $\mathrm{mm}^{2}$ (median 95; range 0-400) in the acetic acid and octreotide treated rats, $\mathrm{p}<0.05$ MannWhitney test) and the lesion score by $64 \%$ (from $5.6(0.5)$ to $2.0(0.5)$ (median 1.5 ; range $0-5$ ),

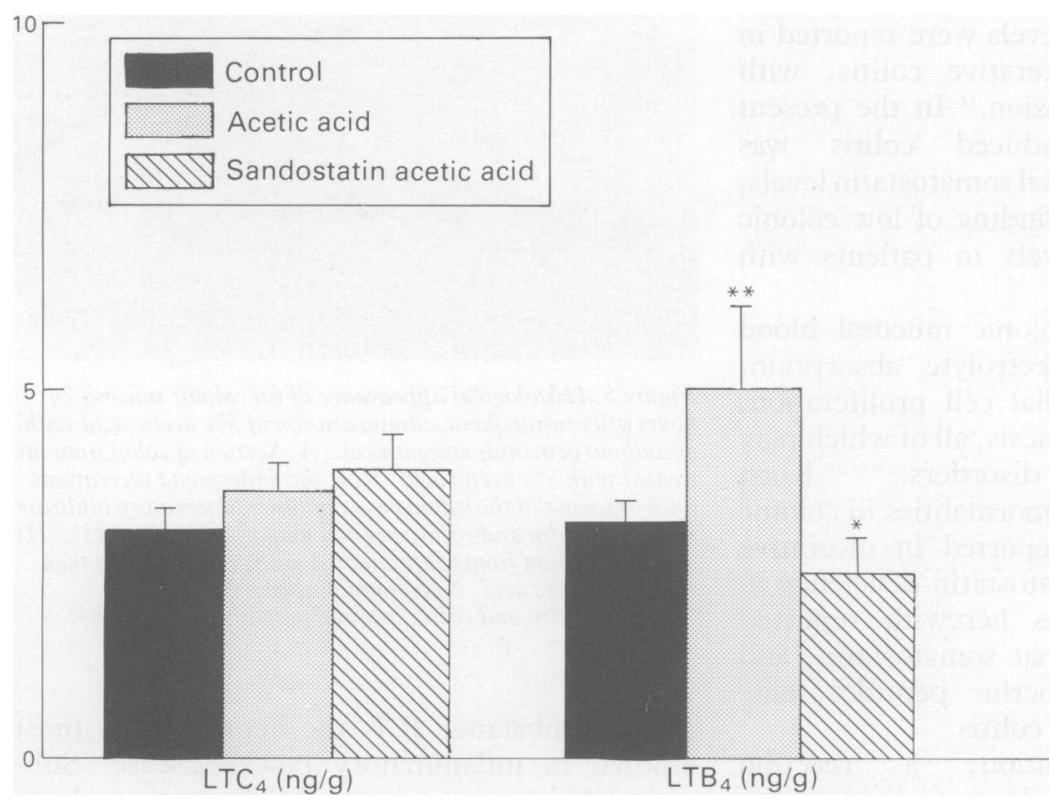

Figure 3: Mucosal leukotriene $B_{4}\left(\right.$ LTB $_{4}$ and leukotriene $C_{4}\left(L T C_{4}\right)$ generation 24 hours after intracolonic administration of $5 \%$ acetic acid with or without octreotide cotreatment. Results are mean (SEM) of 8 to 24 rats per group. ${ }^{\star}$ Significantly different from control rats, $p<0.05$. $\star$ Significantly different from acetic acid treated rats, $p<0 \cdot 05$, Mann-Whitney nonparametric test and Students's t test.
Mucosal neuropeptide concentrations 24 hours after intracolonic administration of 5\% acetic acid with or without octreotide cotreatment

\begin{tabular}{llll}
\hline & Somatostatin & VIP & cGRP \\
\hline Control: & & & \\
Mean (SEM) & $66 \cdot 0(2 \cdot 9)$ & $9 \cdot 6(1 \cdot 1)$ & $1 \cdot 9(0 \cdot 4)$ \\
Median & $66 \cdot 0$ & $10 \cdot 2$ & $1 \cdot 95$ \\
Range & $25 \cdot 1-106(23)$ & $1 \cdot 7-21 \cdot 8(26)$ & $0 \cdot 3-3 \cdot 9(8)$ \\
Acetic acid: & & & \\
Mean (SEM) & $12 \cdot 1(2 \cdot 9)^{\star}$ & $4 \cdot 7(0 \cdot 9)$ & $1 \cdot 3(0 \cdot 3)$ \\
Median & $8 \cdot 15$ & $3 \cdot 7$ & $1 \cdot 7$ \\
Range & $3 \cdot 4-26 \cdot 6(8)$ & $0 \cdot 6-8 \cdot 2(6)$ & $0 \cdot 4-2 \cdot 3(7)$ \\
Octreotide+acetic acid: & $2 \cdot 4(0 \cdot 3)^{\star \star}$ & $2 \cdot 2(0 \cdot 4)$ \\
$\begin{array}{ll}\text { Mean (SEM) } \\
\text { Median }\end{array}$ & ND & 1.9 & 1.9 \\
Range & ND & $1 \cdot 2-4 \cdot 4(7)$ & $1 \cdot 1-3 \cdot 9(6)$ \\
\hline
\end{tabular}

Colonic mucosa (20-30 mg) was frozen in liquid nitrogen, weighed and homogenized in 10 volumes of acetic acid $2 \mathrm{M}$, containing mercaptoethanol and phenylmethylsulfonylfluoride, as described in Methods. Somatostatin, vasoactive intestinal peptide (VIP) (pg/mg), and calcitonin gene related peptide (cGRP) $(\mathrm{fmol} / \mathrm{mg}$ ) were determined by RIA. No of rats in parenthesis. $\star$ Denotes significantly different from controls, $\mathrm{p}<0.05$. $\star \star$ Denotes significantly different from acetic acid treated rats, $\mathrm{p}<0 \cdot 05$.

respectively, $\mathrm{p}<0.05$ ) (Figs 1 and 2). Pretreatment with octreotide, 1 hour before damage induction by acetic acid had similar and even more impressive effects, decreasing the lesion area by $75 \%$ and the lesion score by $84 \%$, although there was no statistical significance between the two treated groups (Figs 1 and 2). Octreotide treatment decreased the segmental weight from $1.02(0.08) \mathrm{g} / 10 \mathrm{~cm}$ to $0.88(0.06)$ $\mathrm{g} / 10 \mathrm{~cm}$ (median $0 \cdot 93$; range $0 \cdot 70-1 \cdot 15$ ).

Morphologically, colonic mucosa of all acetic acid treated rats showed widespread ulcerations with oedaema of the lamina propria and marked polymorphonuclear infiltrate. There were foci of inflammatory cell infiltrates in the muscularis propria and serosa (Fig 5A). In contrast, five out of eight rats treated with octreotide before damage induction had normal looking mucosa without any ulcerations. In the other three rats, the colonic mucosa showed superficial ulcerations with marked oedaema and polymorphonuclear infiltrates into the lamina propria (Fig 5B).

The protection provided by octreotide was accompanied by a significant decrease in diarrhoea, as well as a reduction or return to normal $\mathrm{LTB}_{4}$ levels: from $5 \cdot 6(0 \cdot 5)$ in acetic acid treated rats to $2.56(0.5) \mathrm{ng} / \mathrm{g}$ (median 2.4 ; range $0.76-4.60)$ in octreotide treated rats, and PAF activity from $40.0(3.8)$ to $12.9(3.8) \mathrm{pg} / 10 \mathrm{mg}$ (median 9.5; range $0-33$ ), respectively (Figs 3 and 4).

No differences were found in mucosal cGRP levels when compared with acetic acid treated rats. Mucosal VIP levels, which were low in acetic acid treated rats compared with controls, decreased further when rats were pretreated with octreotide (Table).

\section{Discussion}

Octreotide (sandostatin) is a synthetic cyclic octapeptide with a common 4-amino acid sequence as somatostatin-14, which is responsible for its biological activity. A synthetic substitution enables the impediment of its degradation and, thus, prolongs its half life to 100 minutes.' Octreotide is currently the most 


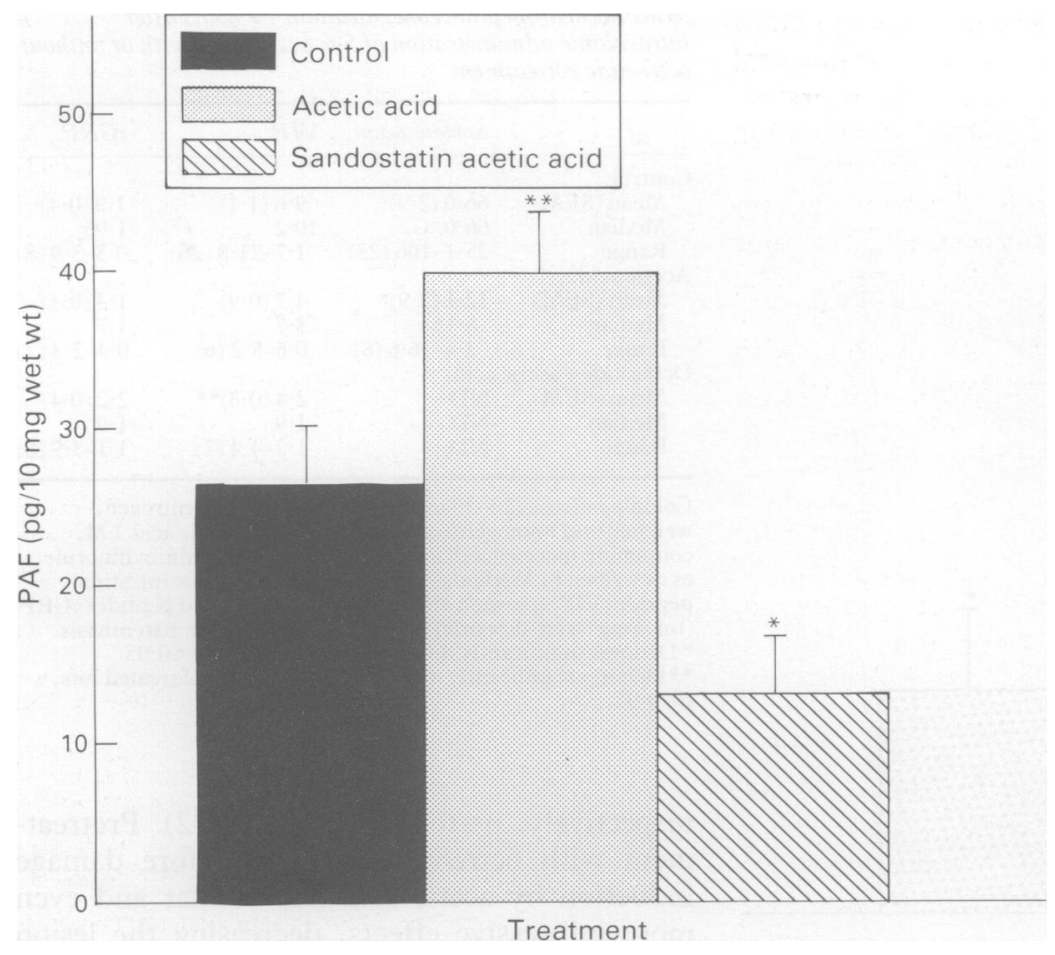

Figure 4: Mucosal platelet activating factor $(P A F)$ activity 24 hours after intracolonic administration of $5 \%$ acetic acid with or without octreotide cotreatment. Results are mean (SEM) of 8 to 11 rats per group. ${ }^{\star} \star$ Significantly different from control rats, $p<0.05$. $\star$ Significantly different from acetic acid treated rats, $p<0 \cdot 05$, Mann-Whitney non-parametric test and Student's t test.

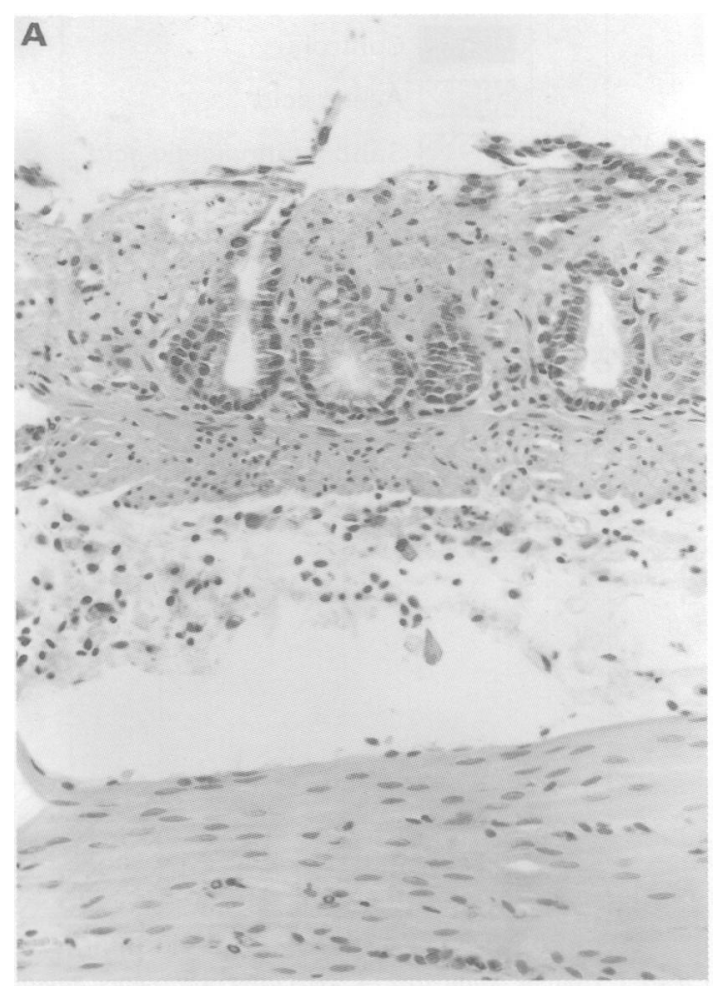

B

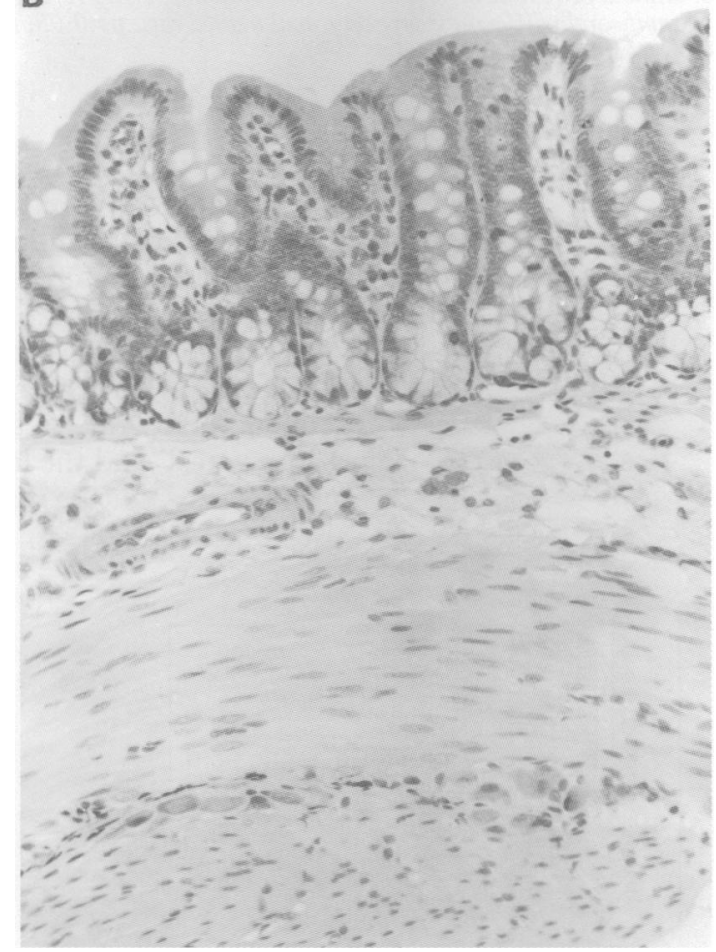

Figure 5: Histological appearance of rat colonic mucosa 24 hours after intracolonic administration of 5\% acetic acid with or without octreotide cotreatment. (A) Section of colon from rat treated with $5 \%$ acetic acid. Note the widespread ulcerations with oedaema of the submucosa and an inflammatory infiltrate $($ Haematoxylin and eosin, original magnification, $\times 183) .(B)$ Section of colon from rat pretreated with octreotide and then with 5\% acetic acid. Note normal appearing mucosa.

(Haematoxylin and eosin, original magnification, $\times 183$ ). the disease. ${ }^{8}$ The results herewith reported support the contention that somatostatin, and possibly other neuroendocrine peptides, take part in the pathogenesis of colitis.

Neurogenic inflammation, a reaction including vasodilatation, plasma extravasation, and smooth muscle contraction, is elicited by mediators released from unmyelinated afferent nerve endings. Substance P, VIP, cGRP, and somatostatin are among the candidate medi- ators. ${ }^{2+}$ Substance $\mathbf{P}$ is the neuropeptide most studied in inflammatory bowel disease. Substance $P$ increases neutrophil lysozyme release and phagocytosis, monocyte chemotaxis, and mast cell secretion, all of which ameliorate inflammatory processes. ${ }^{-4}$ Mantyh et al reported dramatic upregulation of substance $P$ receptor 
binding sites in patients with inflammatory bowel disease and we found high colonic mucosal content of substance $P$ in patients with ulcerative colitis, suggesting that it is involved in regulating the inflammatory and immune responses..$^{25}$ Less is known about the role of VIP in inflammatory bowel disease. VIP is a powerful mediator involved in neurogenic inflammation and intestinal motility. Its concentrations in the mucosal-submucosal layers of patients with active ulcerative colitis were found to be low. ${ }^{27}$ Duffy et al proposed plasma VIP levels as a laboratory supplement to clinical activity index in human inflammatory bowel disease, and Tien proposed VIP to be involved in the diarrhoea associated with mucosal inflammation in rats. ${ }^{28} 29$ We have found that octreotide decreases mucosal VIP levels compared with those found in acetic acid treated rats, thus possibly abolishing its effect on the diarrhoea.

Alpha-calcitonin gene related peptide (cGRP I) is encoded by the calcitonin gene. Patients with medullary thyroid carcinoma have raised plasma cGRP levels and $25 \%$ of these patients present with diarrhoea, the candidate mediators for this response being calcitonin and cGRP. ${ }^{30}$ Exogenous administration of cGRP I to dogs evoked increased small intestinal ion and water secretion and altered colonic chloride secretion in guinea pigs. ${ }^{3132}$ We did not find changes in mucosal cGRP levels in our model of colitis nor any effect of octreotide on mucosal cGRP levels.

In summary, we have found that octreotide significantly reduces colonic mucosal damage caused by $5 \%$ acetic acid. The protective effect was accompanied by reduction in mucosal platelet activating factor activity and mucosal $\mathrm{LTB}_{4}$ and VIP levels. The effects of octreotide in humans remain to be evaluated.

1 Lucey MR, Yamada T. Biochemistry and physiology of gastrointestinal somatostatin. Dig Dis Sci 1989; 34: 5-13S

2 Grosman I, Simon D. Potential uses of somatostatin and its synthetic analogue Octreotide. Am f Gastroenterol 1990; 85: 1061-72.

3 Ferrar JA, Cuthbert AW, Cox HM. The antisecretory effects of somatostatin and analogues in rat descending colon mucosa. Eur F Pharmacol 1990; 184: 295-303.

4 Costa M, Patel Y, Furness JB, Arimura A. Evidence that some intrinsic neurons of the intestine contains somatostatin. Neurosci Lett 1977; 6: 215-22.

5 Dharmsathaphorn K, Sherwin RS, Dobbins JW. Somatostatin inhibits fluid secretion in the rat jejumen. Gastroenterology 1980; 78: 1554-8.

6 Dharmsathaphorn K, Binder HJ, Dobbins JW, Leo L. Somatostatin stimulates sodium and chloride absorption in the rabbit ileum. Gastroenterology 1980; 78: 1559-65.

7 Lehy T, Dubrasquet M, Bonfibs S. Effect of somatostatin on normal and gastric stimulated cell proliferation in the gastric mucosa and intestinal mucosa of the rat. Digestion 1979; 99 : 99-109.

8 Koch TR, Carney JA, Morris VA, Go VLW. Somatostatin in the idiopathic inflammatory bowel diseases. Dis Colo Rectum 1988; 31: 198-203.

9 Ahonen A, Kyosola K, Pentilla O. Enterochromaffin cells and macrophages in ulcerative colitis and irritable colon. Ann Clin Res 1976; 8: 1-7.

10 Kyosola K, Pentilla O, Salaspuro M. Rectal mucosal adrenergic innervation and enterochromaffin cells in ulcerative colitis and irritable colon. Scand F Gastroenterol 1977; 12: 363-7.

11 Bishop AE, Polak JM, Bryant MG, Bloom SR, Hamilton S. Abnormalities of vasoactive intestinal polypeptidecontaining nerves in Crohn's disease. Gastroenterologv 1980; 79: $853-60$.

12 Binimelis J. Webb SM, Mones J, Serrano J, Casamitjana R, Elena M, et al. Circulating immunoreactive somatostatin in
gastrointestinal diseases. Decrease after vagotomy and gastrointestinal diseases. Decrease after vagotomy and enhancement in active ulcerative colitis, irritable bowel syndrome and $931-7$.

13 Eliakim R, Karmeli F, Rachmilewitz D. Decreased somatostatin (SS) generation by cultured colonic mucosa in active ulcerative colitis (UC). Gastroenterology 1991; 100: A578.

14 Vinik A, Moattari AR. Use of somatostatin analog in management of carcinoid syndrome. Dig Dis Sci 1989; 34: 14-27S

15 Maton PN, O'Dorisio TM, Howe BA, McArthur KE, Howard $\mathrm{JM}$, Cherner JA, et al. Effect of a long acting somatostatin analogue (SMS 201-995) in a patient with pancreatic cholera analogue 1 Med 1985; 312: 17-21.

16 Cooper JC, Williams NS, King RF, Barker MC. Effects of a long-acting somatostatin analogue in patients with severe long-acting somatostatin analogue in patients with
ileostomy diarrhoea. Br $\mathcal{F}$ Surg 1986; 73: 128-31.

17 Geerdsen JP, Pederson VM, Kjaergard HK. Small bowel fistulas treated with somatostatin: preliminary results. Surgery 1986; 100: 811-4.

18 Dharmsathaphorn K, Gorelick FS, Shefrwin RS, Cataland S, Dobbins JW, et al. Somatostatin decreases diarrhea in patients with the short bowel syndrome. 7 Clin Gastroenterol 1982; 4: 521-4.

19 Cello JP. Grendell JH, Basuk P, Simon D, Weiss L, Wittner $M$, et al. Effect of octreotide on refractory AIDS-associated diarrhea. Ann Intern Med 1991; 115: 705-10.

20 Sharon P. Stenson WF. Metabolism of arachidonic acid in acetic acid colitis in rats: Similarity to human inflammatory acetic acid colitis in rats: Similarity to human in

21 Wallace JL, Braquet P, Ibbotson GC, MacNaughton WK, Cirinio $\mathrm{G}$. Assessment of the role of platelet activating factor in an animal model of inflammatory bowel disease. $\mathscr{f}$ Lipid Med 1989; 1: 13-23.

22 Agerskov K, Bousfield R, Mortensen PE, Olsen J, Christiansen J. Effect of somatostatin on 133Xe clearance from colonic mucosa before and after local nervous blockade in unanaesthetized man. Scand $\mathcal{7}$ Gastroenterol 1986; 21: $951-4$.

23 Stanisz AM, Befus D, Bienenstock J. Differential effects of vasoactive intestinal peptide, substance $P$ and somatostatin on immunoglobulin synthesis and proliferation by lymphocytes from Peyer's patches, mesenteric lymph nodes and cytes from Peyer's patches, mesen

24 Mayer EA, Raybould H, Koelbel C. Neuropeptides, inflammation and motility. Dig Dis Sci 1988; 33: 71-7S

25 Mantyh CR, Gates TS, Zimmerman RP, Welton ML, Passaro EP Jr, Vigna SR, et al. Receptor binding sites for substance $P$, but not substance $K$ or neuromedin $K$ are expressed in high concentrations by arterioles, venules and lymph nodules in surgical specimens obtained from patients with ulcerative colitis and Crohn's disease. Proc Natl Acad Sci USA 1988; 85: 3235-9.

26 Goldin E, Karmeli F, Selinger Z, Rachmilewitz D. Colonic substance $P$ levels are increased in ulcerative colitis and decreased in chronic severe constipation. Dig Dis Sci 1989; 34: 754-7.

27 Koch TR, Carney JA, Go VLW. Distribution and quantitation of gut peptides in normal colon and ulcerative colitis (UC). of gut peptides in normal colon and
Gastroenterology 1984; 86: A1139.

28 Duffy LC, Zielezny MA, Riepenhoff-Talty M, Byers TE, Marshall J. Weiser MM, et al. Vasoactive intestinal peptide as a laboratory supplement to clinical activity index in inflammatory bowel disease. Dig Dis Sci 1989; 34: 1528-35.

29 Tien XY, Wallace LJ, Kachur JF, Won-Kim S, Gaginella TS Neurokinin A increases short-circuit current across rat colonic mucosa: A role for vasoactive intestinal peptide. 7 Physiol 1991; 437: 341-50.

30 Mason RT, Shulkes A, Zajac JD, Fletcher D, Hardy KJ Martin TJ. Basal and stimulated release of calcitonin gene related peptide in patients with medullary thyroid related peptide in patients with med

31 Reasbeck PG, Burns SM, Sulkes A. Calcitonin gene related peptide: Enteric and cardiovascular effects in dogs. Gastroenterology 1988. 95: 966-71.

32 McCulloch CR, Cooke HJ. Human alpha-calcitonin gene related peptide influences colonic secretion by acting on myenteric neurons. Regul Pept f 1989; 24: 87-96. 